SSCM T

Journal of Sustainable Construction

Materials and Technologies

Journal of Sustainable

Construction Materials

and Technologies

J Sustain. Construct. Mater. Technol. 5(1) (2020) 407-419

www.eds.yildiz.edu.tr/jscmt

\title{
Physical Characterization and Optimization of Fineness Moduli of Natural Sand from The North Region of Cameroon Used in Construction
}

\author{
Bertin Pagna Kagonbé ${ }^{1,2, *}$, Désiré Tsozué ${ }^{2}$, Yaceinthe Djépaze II ${ }^{1,3}$ Aubin Nzeukou \\ Nzeugang ${ }^{2}$, Achille Madi Balo ${ }^{1}$, Simon Djakba Basga ${ }^{4}$, Simon Ngoss III ${ }^{5}$ \\ ${ }^{1}$ Local Materials Authority Promotion (MIPROMALO), B.P. 2396 Yaoundé, Cameroon \\ ${ }^{2}$ Department of Earth Science, Faculty of Science, University of Maroua, B.P, 814 Maroua, Cameroon \\ ${ }^{3}$ Departments of Physics Science, Faculty of Science, University of Ngaoundéré, B.P, 454 Ngaoundéré, Cameroon \\ ${ }^{4}$ Institute of Agricultural Research for Development (IRAD), P.O. Box 415 Garoua, Cameroon \\ ${ }^{5}$ Departments of Mines, Petroleum, Gas and Water Resources Exploration, Faculty of Mines and Petroleum Industries,
}

University of Maroua, Cameroon.

Manuscript Received September 11, 2019; Accepted March 29, 2020

\begin{abstract}
This paper deals with the physical characterization and the optimization of fineness moduli of some natural sand samples for their appropriate valorization in construction in North Cameroon. Five sands samples (SN5, SB1, SB2, SB3 and SB4) were selected from various locations. Tests conducted include Particle size analysis, Organic impurities, Sand Equivalent and Bulk density. Fineness Modulus (FM), Mean grain, Sorting index (Si), Skewedness index and Uniformity coefficient have been deducted mathematically. Results shown that the particle size distribution curves of the studied sands have an "S" shape. The sand equivalent values vary between 91.1 and $96.8 \%$, characteristic of very clean sand. The fineness moduli values vary between 1.9 and 3.4 except for samples SB1 and SB2 which are coarser with values of 3.4 and 3.3 respectively. Others results shown that all the sands are pure (impurity level less than $0.5 \%$ ), well classified Sorting index $\mathrm{Si}<0.35$ ) and Coefficient of uniformity $(\mathrm{Cu}<2)$. Studied sands are globally coarse (skewedness index between -0.35 at $-0.79 \Phi)$. Only SB4 and SN5 satisfy the NF EN 933-1 gradation limits. Combinations of SB3 (FM = 2.1) with SB1 (FM =3.4) or SB2 $(\mathrm{FM}=3.3)$ were carried out to get desired sand gradation (2.2 to 2.8), SB4 and SN5 having already good fineness moduli of 2.6 and 2.8 respectively.
\end{abstract}

\footnotetext{
${ }^{*}$ Corresponding Author:

E-mail address: kagonbebertin@gmail.com (B.P. Kagonbé.)
} 


\section{Introduction}

Advances in the development of concrete for intended use are gaining high interest nowadays. The list of different types of concrete, each suitable for a specific utility, is lengthy. Some of the types worth mentioning are, structural lightweight concrete, heavy weight concrete in its entirety, as construction material is gaining popularity (Mane et al., 2017). Sand is a naturally occurring granular material composed of finely divided rock and mineral particles (Deer et al., 1966; Friedman et al., 1979; Sabih et al., 2016; Magudeaswaran. et al., 2016). The composition of sand is highly variable, depending on the local rock sources and conditions. In composition, silica $\left(\mathrm{SiO}_{2}\right)$ is the predominant oxide. Mineralogically, they consist of quartz resulting from the disintegration of granites, sandstone and similar rocks by natural processes of weathering and erosion (Saidi et al., 2004; Mhedhebi et al., 2015; Koirala et al., 2017). Generally, commercial sand is obtained from river beds or from sand dunes originally formed by the action of winds. The usual particle size of sand grains is between 0.075 and $4.75 \mathrm{~mm}$ with further subdivision of coarse sand in range of $2 \mathrm{~mm}$ to $4.75 \mathrm{~mm}$, medium sand in range of $0.42 \mathrm{~mm}$ to $2 \mathrm{~mm}$ and fine sand between $0.075 \mathrm{~mm}$ to $0.42 \mathrm{~mm}$ (Terzaghi et al., 1996). The main use of sand as a fine aggregate is in the manufacture of concrete. Concrete is a composite material which mainly consists of cement, sand or aggregate, water and other additional material in a given proportion. As a composite material, the quality of concrete relies on the quality of each of its constituent. Sand is commonly used as fine aggregate, which is more than 30 percent of the total volume of concrete (Akinboboye et al., 2015; Sabih et al., 2016). Consequently, the characteristics of sand significantly affect the performance of fresh and hardened concrete and have an impact on the cost effectiveness of concrete (Hudson, 1999; Ahmad and Mahmood, 2008; Alexander and Bertron, 2013; Makhloufi et al., 2014; Ngugi et al., 2014; Reddy et al., 2015; Sabih et al., 2016; Tebbaland Rahmouni, 2016). Gradation or particle size distribution of sand affects the properties of concrete like packing density, voids content, workability and strength (Goltermann et al., 1997; Obla, 2011; Pedersen, 2011; Sabih et al., 2016). Increase in demand and decrease from natural sources of fine aggregate for the production of concrete has resulted in the need to identify new source of fine aggregate. Due to increased levels of construction expected in the forthcoming years, it is expected that fine aggregates suitable for use in concrete will become scarce or uneconomical to produce.

Currently in Cameroon, rapid population growth (19.406.100 inhabitants in 2010 and 24.969.104 in 2018 (United Nations-WPP, 2011; National Institute of Statistics, 2010), rural exodus and the mobility of public and private sector employees have resulted in a rapid growth of urban centre. The rate of urbanization has increased from $28.5 \%$ in 1976 to $52 \%$ in 2010 according to the $3^{\text {rd }}$ general census of population and housing done in 2010 by the National Statistics Institute (National Statistics Institute, 2010). These phenomena rhyme with the housing deficit, estimated to be above one million units, leading to the rapid development of the building and construction sector and public works (National Institute of Statistics, 2010). So the construction of social housing in urban centres for example, to overcome this housing deficit, leads to a greater demand for construction materials in general and sand in particular.

In North Cameroon, the exploitation of sand involves a number of actors from truck owners, drivers and loaders to contractors or other individuals. However, the choice of this material is often based on user's experience that is not sufficient to guarantee the quality of the works and consequently, good economic returns of real estate investments. From this observation, and for a more appropriate valorization, it's necessary to check the conformity of these granular materials to the normative constraints. The main objective of this experimental work is the physical characterization and optimization of finesse modulus of natural sand. The result of the paper could be helpful guide for a more appropriate valorization of sand in construction in North Cameroon.

\section{Experimental Method}

\subsection{Study Area}

The study area is located in Cameroon (North Region), between latitudes 9 $9^{\circ} 12^{\prime} 20^{\prime \prime}$ and 9 $20^{\prime} 00^{\prime \prime} \mathrm{N}$ and longitudes $13^{\circ} 24^{\prime} 80^{\prime \prime}$, and $13^{\circ} 18^{\prime} 20^{\prime \prime}$ E (Fig. 1). The climate is a Sudanese type, characterized by an annul rainfall between 1000 and $1100 \mathrm{~mm}$ and mean annual air temperature of $28^{\circ} \mathrm{C}$ (Olivry, 1986). The vegetation consists of tall grasses, deciduous trees and savannahs (Letouzey, 1985). The topography of the area is dominated by sandstone hills (Bessong et al., 2011). Geological formations include quartzite, micaschists, gneisses and migmatites (Ngounouno et al., 2001 ; Ngounouno et al., 2003; Mbowou et al., 2011). The superficial formations are constituted of ferruginous soils and vertisols (Raunet, 2003; Tamfuh et al., 2011). 


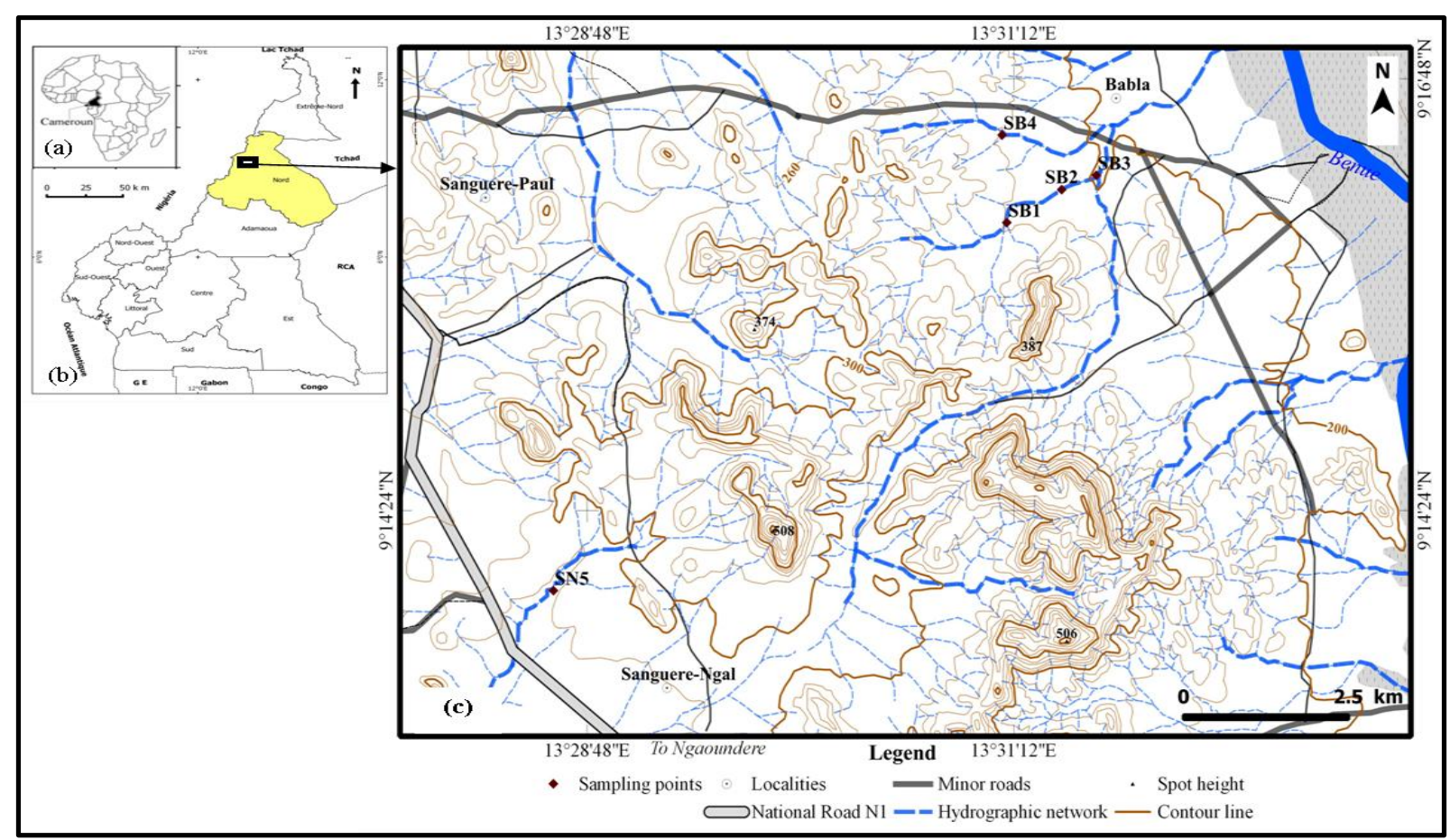

Figure 1. (a) Location of Cameroon in Africa, (b) Location of North Region in Cameroon, (c) Location of the study area

\subsection{Methods}

Field trips consisted of many expeditions in various sand extraction points. Five sand samples (SB1, SB2, SB3, SB4 and SN5) were collected from five sand extraction points along the Babla and Sanguéré-Ngal rivers, located south of Garoua town, in the North region of Cameroon (Fig. 1). The positions of each sampling point were determinate using the GPS Garmin. In each extraction point, $30 \mathrm{~kg}$ of sand sample was collected for grading and testing in the laboratory. Sand samples were pre-treated by washing with distilled water (Wilde et al., 1970) and drying in an oven at $105^{\circ} \mathrm{C}$ for 48 hours. After drying, all samples were sieved using a SIEVES-TRONIC sieve column in the Materials testing laboratory of the Local Materials Authority Promotion (MIPROMALO) following the NF EN 933-1 standard. The remaining fraction of each sieve was weighed and the particle size distribution curve obtained. The sand equivalence was determined from the sand equivalent apparatus in the National Laboratory of Civil Engineering of Cameroon (LABOGENIE) following the NF EN 933-8 standard. Table 1 gives the recommended values of sand equivalence according to Dreux et al., 1978.

Table 1. Recommended values of sand equivalence (Dreux, 1978).

\begin{tabular}{|c|c|c|}
\hline ES a piston & Nature of sand & Quality of sand \\
\hline $\mathrm{ES}<30$ & Pure clayey sand & Rejected for concrete \\
\hline $30<\mathrm{ES}<60$ & Clayey sand & $\begin{array}{l}\text { Risk of shrinkage or swelling. } \\
\text { Rejected for quality concrete. }\end{array}$ \\
\hline $60<\mathrm{ES}<70$ & Lose clayey sand & $\begin{array}{l}\text { Admissible properties for frequent quality concrete when } \\
\text { shrinkage is not particularly disturbed. }\end{array}$ \\
\hline $70<\mathrm{ES}<80$ & Clean sand & $\begin{array}{l}\text { A little percentage of fine clays. } \\
\text { Suitable for concrete of high quality. }\end{array}$ \\
\hline $\mathrm{ES}>80$ & Very clean sand & $\begin{array}{l}\text { Almost total absence of fine clay. } \\
\text { Risk of causing plasticity shortage. }\end{array}$ \\
\hline
\end{tabular}

The organic matter content was determined through calcination in a furnace at $500^{\circ} \mathrm{C}$ for three hours according to NF P94-050 standard. The Munsell Soil Color Chart (2014) was used for color appreciation. The observation of the morphology of the grains was made by means of a magnifying glass. Bulk Density: An empty $100 \mathrm{ml}$ 
measuring cylinder is placed on the weighing machine and the reading on the machine is set to zero. Next, the measuring cylinder is filled with the sand sample until the reading is $100 \mathrm{ml}$. The reading is taken and bulk density is calculated from equation (Bulk Density, $\rho=$ weight of dry sand (g)/ Volume of dry sand).

Some particle size distribution parameters were deducted mathematically. Fineness Modulus refers to the fineness or coarseness of aggregate. This is the summation of cumulative percentage of materials retained on the standard sieves divided by 100 . The classification of sand by its modulus of finesse is given on table 2 . The Fineness Modulus (FM) has been determined according to the following equation (1) proposed by Lefeu and Francy (1999):

$$
\mathrm{FM}=\frac{\operatorname{Qr}(0.08)+\operatorname{Qr}(0.125)+\operatorname{Qr}(0.315)+\operatorname{Qr}(0.5)+\operatorname{Qr}(1)+\operatorname{Qr}(2)+\operatorname{Qr}(3.15)}{100}
$$

Table 2. Field of sand usage in function of its fineness modulus (Amey et al., 2014)

\begin{tabular}{|c|c|c|c|}
\hline Usage in concrete & Sand nature & $\begin{array}{l}\text { Fineness } \\
\text { modulus }\end{array}$ & Observations \\
\hline \multirow[t]{2}{*}{ Non authorised sand } & Over fine sand & $<2.1$ & \\
\hline & $\begin{array}{l}\text { Slightly over fine } \\
\text { sand }\end{array}$ & 2.1 to 2.5 & $\begin{array}{l}\text { Usable sand if particularly aiming to ease } \\
\text { implementation in affecting probably the } \\
\text { resistance. }\end{array}$ \\
\hline \multirow[t]{2}{*}{ Admissible sand } & $\begin{array}{l}\text { Medium sand } \\
\text { (preferable) }\end{array}$ & 2.5 to 3.1 & $\begin{array}{l}\text { Sand that is more suitable to obtain a satisfying } \\
\text { workability and a good resistance with } \\
\text { segregation risk limited. }\end{array}$ \\
\hline & $\begin{array}{l}\text { Slightly medium } \\
\text { coarse sand }\end{array}$ & 3.1 to 3.5 & $\begin{array}{l}\text { Usable sand to explore high resistance but poor } \\
\text { workability and risk of segregation. }\end{array}$ \\
\hline Non authorised sand & Over coarse sand & $>3.5$ & \\
\hline
\end{tabular}

The Mean grain (Mg), the Sorting index (Si) and the Skewness (Ski) were determined according to Folk and Ward (1957), based on phi $(\Phi)$. Unit ( $\Phi=-\log _{2} \mathrm{~d}$, where $\mathrm{d}$ is the diameter of the particle in $\mathrm{mm}$ ).

$$
\begin{aligned}
& \mathrm{Mg}=\frac{(\mathrm{Q} 16+\mathrm{Q} 50+\mathrm{Q} 84)}{3} \\
& \mathrm{Si}=\frac{(\mathrm{Q} 84-\mathrm{Q} 16)}{4}+\frac{(\mathrm{Q} 95-\mathrm{Q} 5)}{6,6} \\
& \mathrm{Ski}=\frac{(Q 16+Q 84-2 Q 50)}{2(Q 84-Q 16)}+\frac{(Q 5+Q 95-2 Q 50)}{2(Q 95-Q 5)}
\end{aligned}
$$

Where $\mathrm{Q}_{5}, \mathrm{Q}_{16}, \mathrm{Q}_{50}, \mathrm{Q}_{84}$ and $\mathrm{Q}_{95}$ correspond to the hypothetical sieve meshes on which x\% by weight. The Uniformity coefficient $(\mathrm{Cu})$ was determined by the formula

$$
\mathrm{Cu}=\frac{\mathrm{d} 60}{\mathrm{~d} 10}
$$


Where $\mathrm{d}_{60}$ is the effective particle diameter corresponding to $60 \%$ by weight of the passing and $\mathrm{d}_{10}$ the effective particle diameter corresponding to $10 \%$ by weight of the passing.

However, if necessary, it is possible to modify the fineness modulus of these sands by combining with SB3 (finer sand) in order to obtain a sand whose finesse modulus meets the intended characteristics for use in concrete. The optimization phase consisted to take SB3 (FM=2.1) and mixing with SB1 $(\mathrm{FM}=3.1)$ or SB2 $(\mathrm{FM}=3.3)$ in different combinations to get desired sand gradation (2.2 to 2.8).

\section{Results and Discussions}

\subsection{Particle size Distrubition}

The particle size distribution curves of the studied sands have an "S" shape (Fig.2), characteristic of the common curves obtained in sands consisting of elements of various sizes (Dupain et al., 2009). The curves of the studied sands from one site to another vary very little with the exception of SB3; which is constituted mainly of fine sand. Various studies have shown that the particle size distribution of fine aggregate plays a very important role on the workability and segregation of fresh concrete (Johansen, 1989; Bédérina et al., 2005; Ben et al., 2014). Several authors claim that uniformly distributed mixtures produce better workability than gap-graded mixtures (Glavind et al., 1993; Golterman et al., 1997; Makhloufi et al., 2014), although higher slumps could be achieved with gapgraded mixtures. Indeed, the particle size distribution of the studied sand shows that the samples are constituted of mixtures in varied proportions.

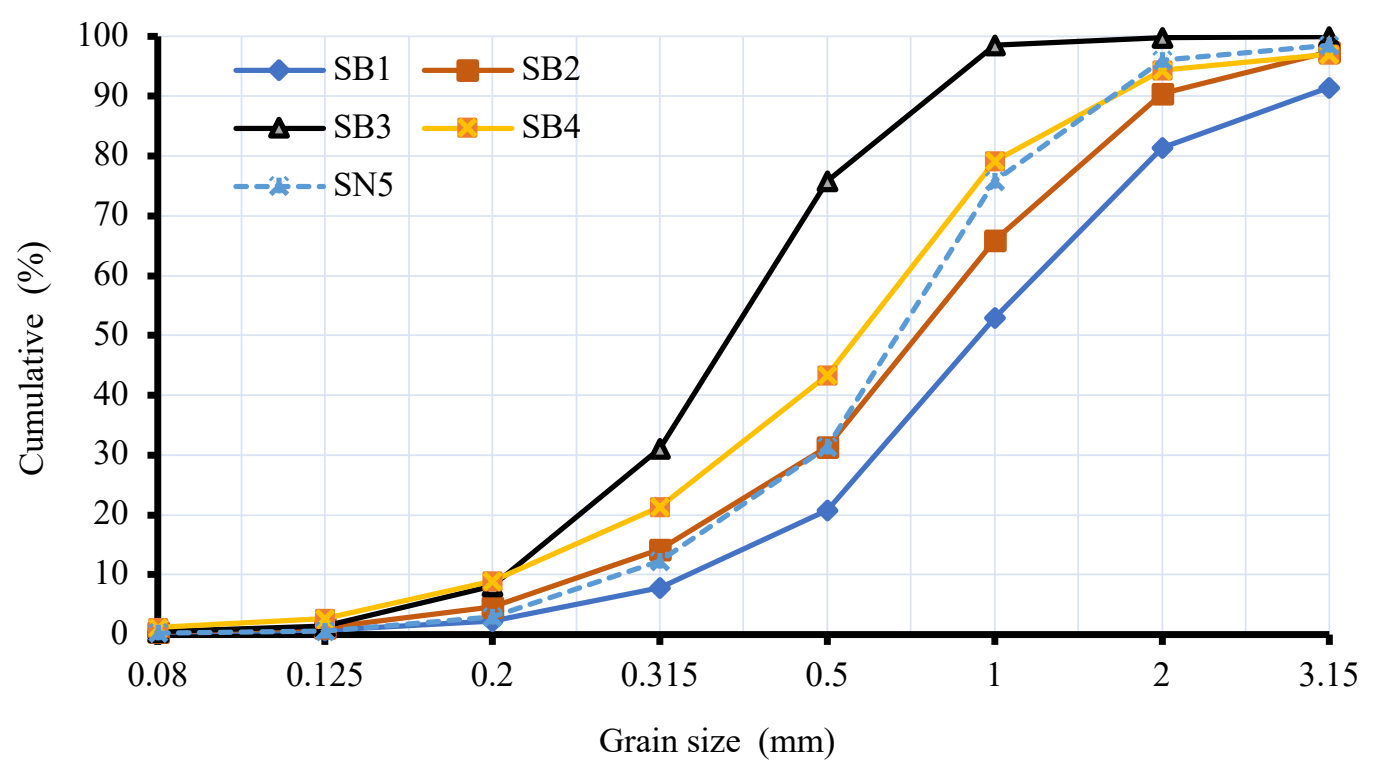

Figure 2. Grain size distribution curves

\subsection{Some Physical Properties of the sands studied}

Table 3 presents some physicals properties of the studied sands. Size and shape of the studied samples observed by magnifying glass shown that some particles are yellowish brown, brilliant and others are quite dark. The surface texture of particles reveals that a majority of the sand samples had sub-angular shaped particles while others are sub-round shaped particles. These sub angular shaped particles confirm the immediate environment origin, especially from weathering and disintegration products sandstone. Several studies have shown that, the grain shape, texture and the nature of sand influenced the properties of fresh and hardened state of concrete (Alexander, 1989; Mehta and Monteiro 1993; Shilstone, 1999; Mahaut et al., 2008; Westerholm et al., 2012; Saaid et al., 2011; Makhloufi et al., 2014; Huang and Wang, 2017; Poloju et al. 2017; Kumar and Sashidhar, 2018). They affect the workability, the strength and the durability characteristics of hardened concrete (Bashar et al., 2014). In 
other hand, highly angular particles require more water for their wetting but may provide better interlocking. Rounded aggregate contain fewer voids which result into higher workability. Hence, angular particles of aggregates tend to more packed, and possess higher strength and durability in hardened mix of concrete and mortar (Kaplan et al., 1958). The studied sand have sub-angular grains, so their use in concrete does not require much water. Their value of organic impurities varies from $0.36 \%$ (SB2) to $0.43 \%$ (SN5, Table 6). Those values were less than $0.5 \%$, which is the acceptable limit according to the ASTM C40 (2004). The high organic impurities content in sand influence the properties of the resulting concrete (Kaplan et al., 1958), as it significantly reduces the compressive strength of the concrete (Xudong et al., 2012; Ngugi et al., 2014).

Table 3. Some physical properties and granular parameter of studies sands

\begin{tabular}{lccccc}
\hline Samples & SB1 & SB2 & SB3 & SB4 & SN5 \\
\hline Colour & \multicolumn{7}{c}{ Yellowish brown color and opaque grains } \\
Morphology & \multicolumn{7}{c}{ Sub-angular to Sub-rounded grains } \\
Organic matter & 0.4 & 0.36 & 0.39 & 0.42 & 0.43 \\
Fines particles $<80 \mu \mathrm{m}(\%)$ & 1.6 & 3.3 & 3.8 & 9.1 & 1 \\
Bulk density $\left(\mathrm{g} / \mathrm{cm}^{3}\right)$ & 2.5 & 2.52 & 2.54 & 2.55 & 2.52 \\
Fineness Modulus (FM) & 3.4 & 3.3 & 1.9 & 2.6 & 2.8 \\
Sand equivalent (ES) en (\%) & 91.22 & 92 & 91.1 & 94.25 & 96.8 \\
Mean grain $(\mathrm{Mg})$ & 0.94 & 0.94 & 0.34 & 0.57 & 0.17 \\
Sorting index (Si) & -0.39 & -0.39 & -0.13 & -0.48 & -0.29 \\
Skewness index (Ski) & -0.79 & -0.79 & -0.11 & -0.42 & -0.35 \\
Coefficient of uniformity $(\mathrm{CU})$ & 0.25 & 0.16 & 0.63 & 0.31 \\
\hline
\end{tabular}

The percentage of fines particles smaller than $80 \mu \mathrm{m}$ varied from 1\% (SN5) to $9.1 \%$ (SB4) (Table 1). Except for sample SB4, other samples can be considered as clean sands (fine particles content ranging from 1 to $3.8 \%$ ); the finer particles content has a significant influence on the water demand and the workability of the mortar (Kronlof, 1994; Sujatha et al., 2012). This effect is even more pronounced in the presence of lower proportion of water and higher proportion of fines grains in the sand (Mehta et al. 1986; Bédérina et al., 2005; Westerholm et al. 2008).

The uncompacted bulk densities of the studied sands are situated between $2.50 \mathrm{~g} / \mathrm{cm}^{3}$ and $2.55 \mathrm{~g} / \mathrm{cm}^{3}$ (Table 6) roughly close from one site to another. The values obtained are relatively close to those obtained in some studies carried out in the same region (Kamga et al. 2016).

\subsection{Sand Equivalent}

Sand Equivalent values vary between 91.1 and $96.8 \%$. According to the NF EN 933-8 standard, the studied sands are classified as very clean sands. Despite the almost total absence of fine clay particles that could lead to the risk of plasticity defects in concrete, these sands offer opportunities to be used in conventional concrete works if the resistance of structures is sought (NF EN 933-8). However, high sand equivalent values have a positive effect on concrete properties (Hasdemir, 2004). 


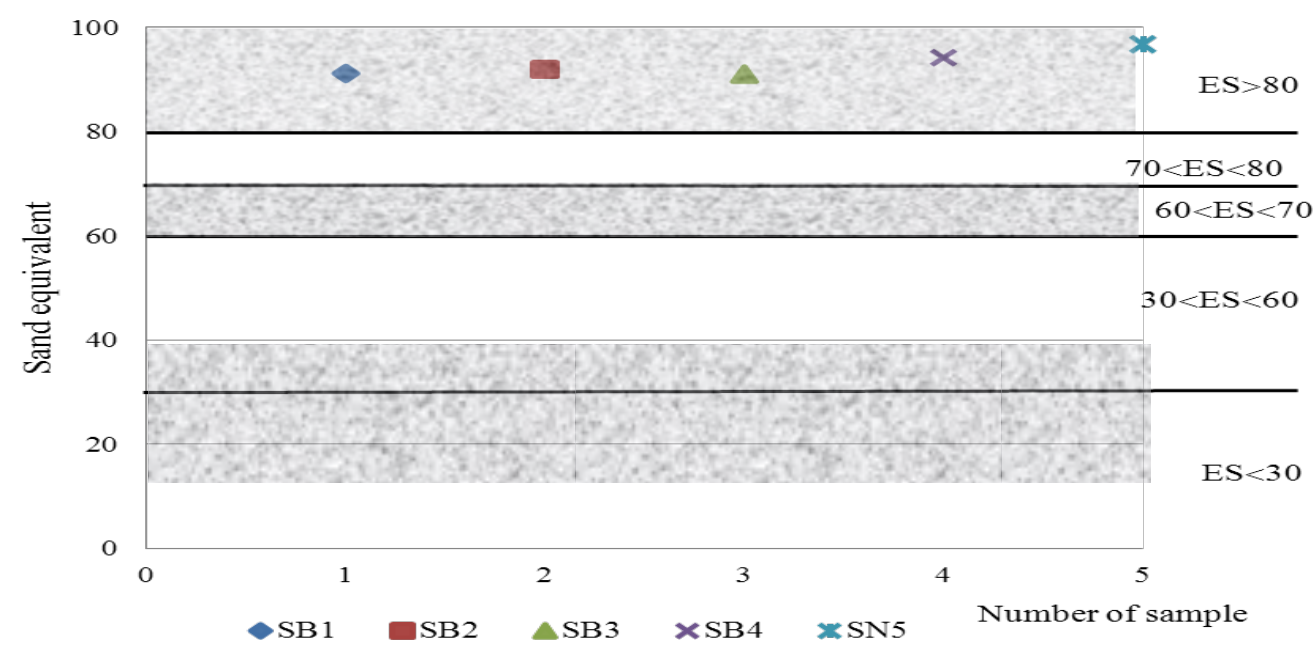

Figure 3. Sand equivalent (\%)

\subsection{Distribution of Indices}

A wide variation is observed in the values of fineness modulus of different sands (Fig.4 and Tab.2). The fineness modulus value (FM) varies between 1.9 (SB3) and 3.4 (SB1). Except for SB3 sand which can be classified as fine sand category, other values correspond to the preferential value of sand fineness modulus for an application in the construction of concrete structures (NF EN 933-1 Standards). According to the experimental investigation for a good manoeuvrability (Amey et al., 2014), SB4 and SN5 are suitable for conventional concrete works whose resistance and stability are sought. SB1 and SB2 with FM of 3.4 and 3.3 respectively, they can be classified in the category of little too coarse sands.

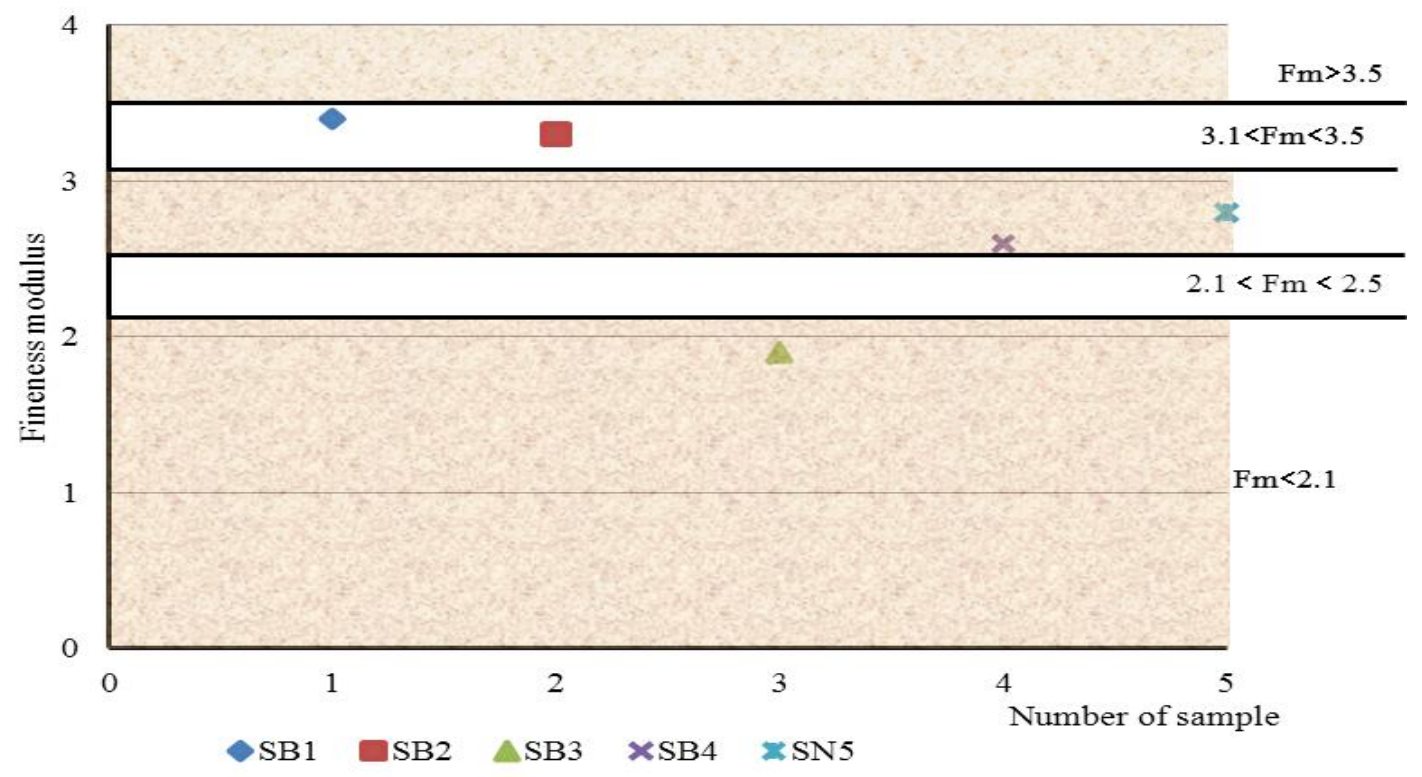

Figure 4. Natural Fineness modulus

Mean grain size values of all samples oscillate between $0.17 \Phi$ and $0.94 \Phi$, globally below1 $\Phi$ which corresponds to coarse sands (Tab.3). This small variation in the mean particle size of the studied sands could be explained by their common origin. 
The sorting index of the studied sands makes it possible to give an indication of the grain size sorting. The results show that, all the sorting index values are less than 0.35 (Fig. 5). According to Folk and Ward (1957), they are very well classified sands, in agreement with the shape of the grain size curves obtained.

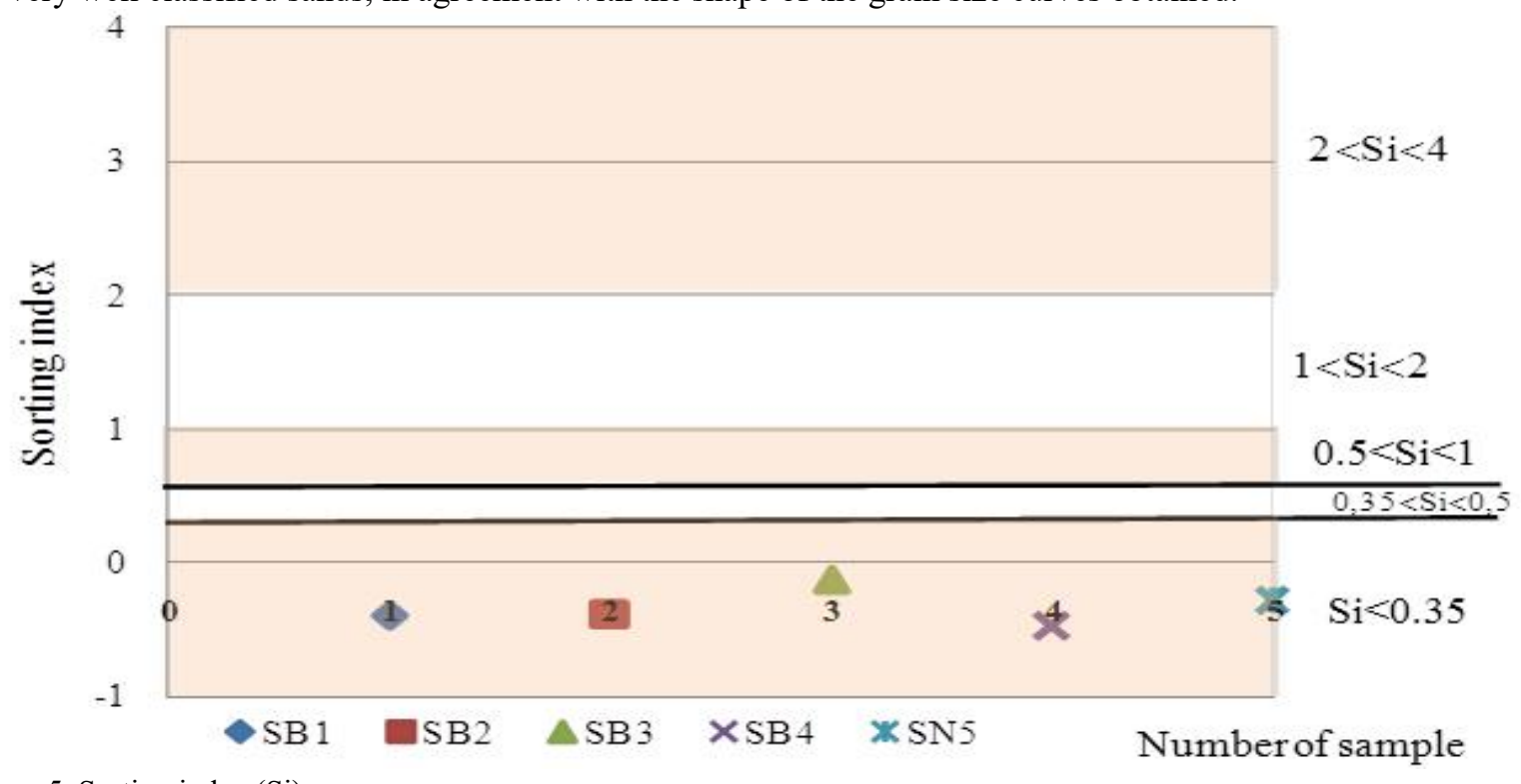

Figure 5. Sorting index (Si)

The Skewness index determines the deviation of the grain size curve from the Gaussian curve. With the exception of sample SB3 (Ski = - $0.11 \Phi)$ which has an asymmetrical grain size curve with a tendency towards fine grains, the particle size distribution of the majority of samples have Skewness index values ranging between -0.35 $\Phi$ and $-0.79 \Phi$ (Fig. 6), which means that the curves are very asymmetrical towards the coarse ones (Folk and Ward 1957).

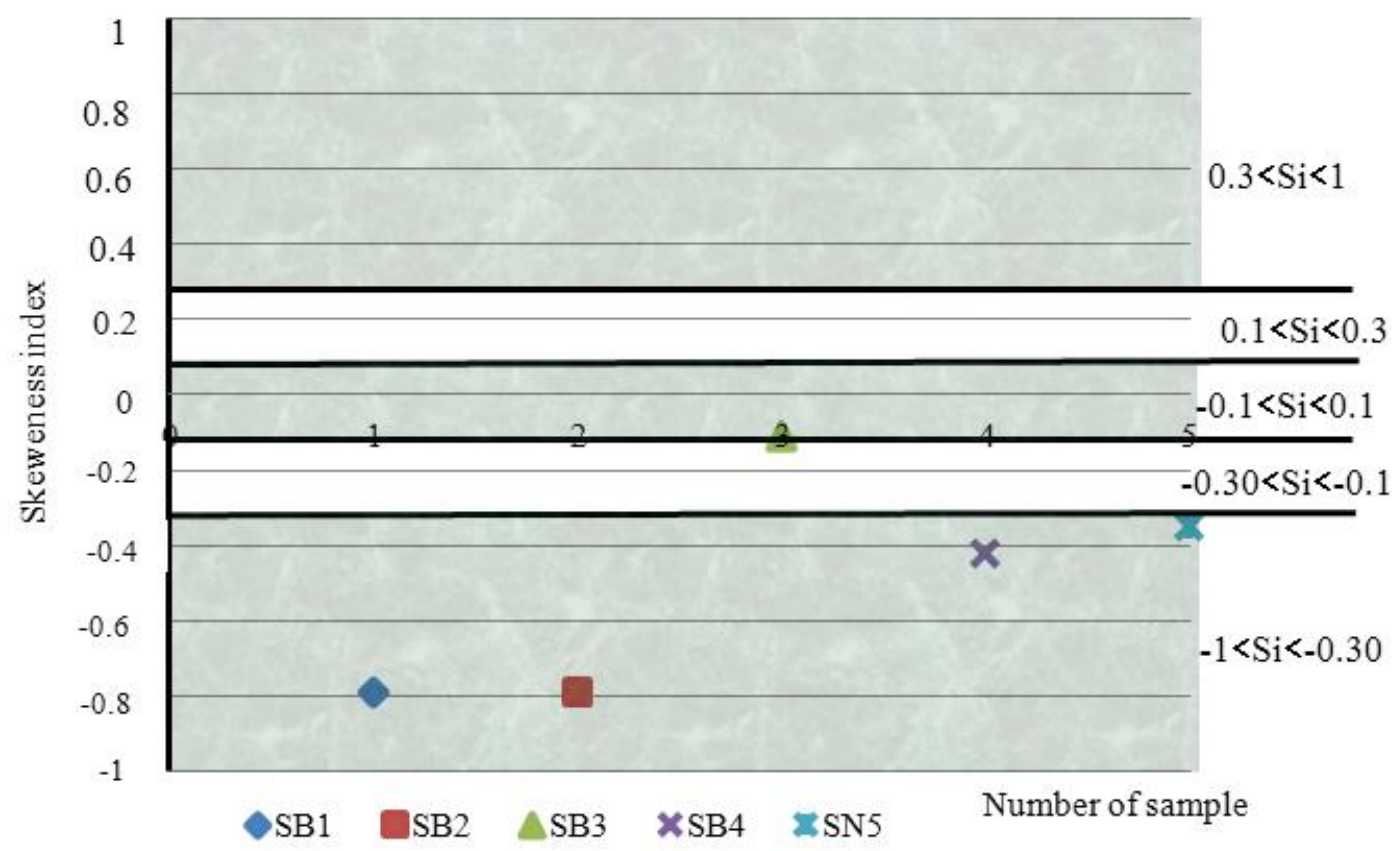

Figure 6. Skewedness index (Ski)

The uniformity coefficient values of sand samples vary between 0.16 and 0.63 . They are less than 2 . The sands have thus an essentially uniform particle size. Uniformly distributed mixtures generally lead to higher packing resulting in concrete with higher density and less permeability (Johansen, 1989; Glavind, 1993; Golterman, 1997) 
and improved abrasion resistance (Mehta et al., 1993). Consequently, they require less paste, thus decreasing bleeding, creep, and shrinkage (Shilstone, 1999).

\subsection{Optimization of The Fineness Modulus}

Several authors have studied the effect of fineness modulus of sand on the properties of concrete. They showed that the Fineness Modulus of sand was among the principal factors affecting the workability, strength, durability, plastic viscosity, density and permeability of fresh and hardened concrete (Abrams, 1920; Shilstone, 1990; Bédérina et al., 2005; Sabih et al., 2016; Kumar and Sashidhar, 2018). Generally, FM of 2.1 to 2.5, 2.5 to 3.1 and 3.1 to 3.5 indicate that the sand is slightly over fine, medium and slightly medium respectively. It is admitted that very coarse sand or very fine sand produces poor concrete mixes. Coarse sand results in harsh concrete mixes prone to bleeding and segregation. Fine sand requires a comparatively large amount of water to achieve the desired concrete workability and is prone to segregation and may require higher cement contents. Bédérina et al. (2005) showed that the correction of the granular distribution by means of mixing two local sands in predetermined proportions has allowed optimizing compactness and workability. Quiroga and Fowler (2003) concluded from experimental research that admixtures can be used successfully to enhance workability of fresh high-microfines mortar and high-microfines concrete without producing harmful effects on hardened concrete properties such as compressive strength and drying shrinkage. The studies of Sabih et al. (2016) showed that the optimization of fineness modulus improves more than $8 \%$ to $39 \%$ in concrete strength. In fact, the effects of fineness modulus are much more important than the effects of coarse aggregate. The optimized gradation diagram matched with the NF EN 933-1 limits and the optimized fineness modulus reached within the NF EN 933-1 limits.

The values of the fineness modulus presented in table 1 show that certain studied sands are likely to be improved with an aim to obtain sand whose fineness modulus satisfies the desired characteristics. The combined use of these sands could contribute to the improvement of the quality of the works. Fig. 8 and Fig. 9 show the possibilities of modifying the fineness modulus of SB3 sands by combination with SB1 or SB3 with SB2. In fact, only samples SB4 and SN5 satisfy the limits of good fineness modulus with 2.6 and 2.8 respectively. In this range, the concrete that we can obtain with these two sands will have good workability, strength and flexibility. So, for high performances buildings, only SB4 and SN5 must be use according to their fineness modulus. But, we can combine a very fine sand and a coarse sand to obtain a desire sand with a good fineness modulus. Coming back to Fig. 8 and 9 , we can notice that, to obtain a fineness modulus material ranging between 2 and 2.80 , it is necessary to take sands SB1 and SB3 or SB2 and SB3 in indicated proportions according to the diagrams (figure 8 and 9) For example, the mixture of the sands SB1 and SB3 with the fineness modulus respectively equal to 3.4 (to coarse) and 1.9 (to fine) took to the same proportions, gives a sand with a fineness modulus of 2.65 which is very good for concrete. With this theoretical work, we showed that is possible to use two sands with bad fineness moduli to obtain a good one just by combination the two in appropriate proportions.

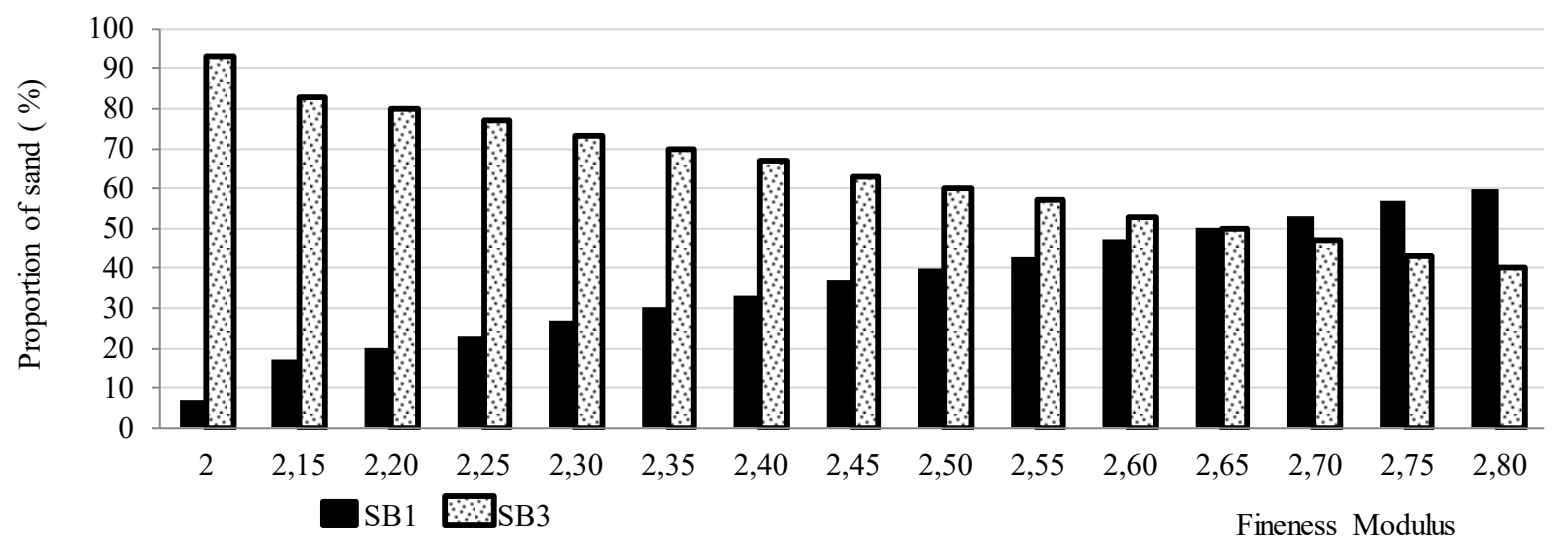

Figure 8. Possible combinations SB1 and SB3 for obtaining FM sand suitable for application in concrete. 


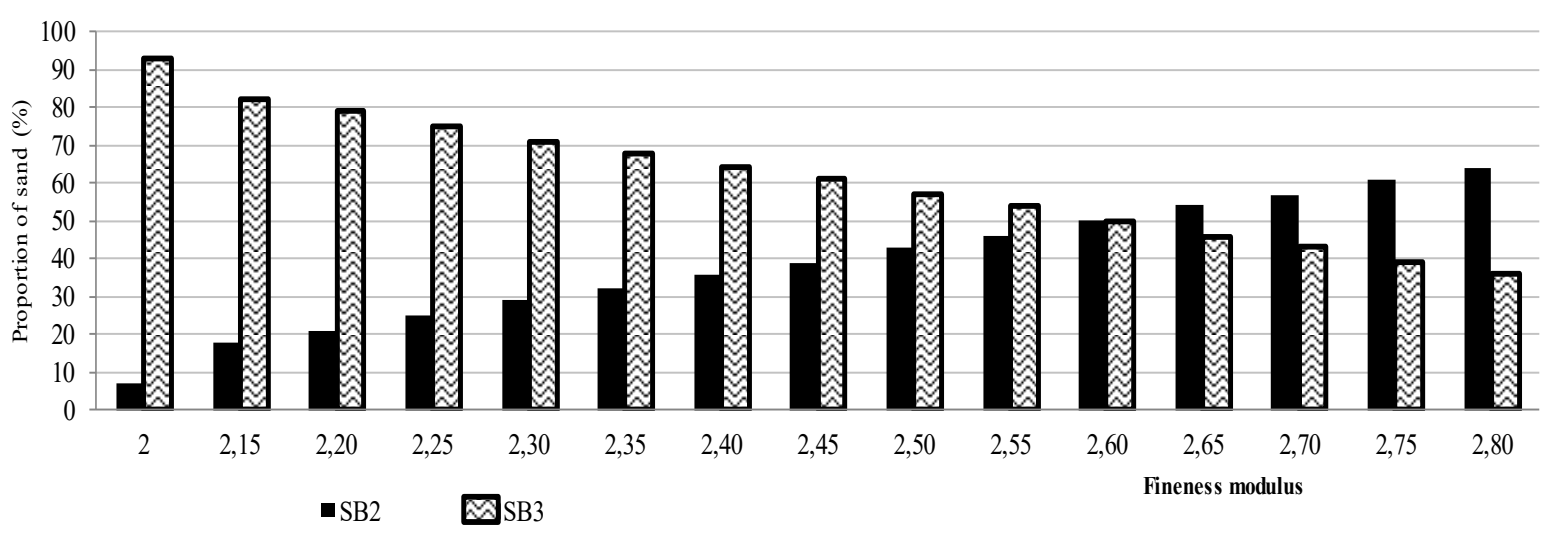

Figure 9. Mixing possible SB2 and SB3 to obtain sand at the FM acceptable for application in concret

\section{Conclusion}

Physical characterization and optimization of fineness moduli of natural sand for appropriate use in construction was carried out in the aim to verify the compliance of sands used in concrete works in North Cameroon. According to the five samples studied, the following conclusions are drawn:

- The studied sands classified as medium sands to little too coarse sand, have an "S" shape granulometry curve with sub-angular-shaped particles which confirms their immediate environment origin.

- Only samples SB4 and SN5 satisfy the limits of good fineness modulus with 2.6 and 2.8 respectively. However, fine (unsuitable) sands (SB3) can be optimized by adding different percentages of various fractions of coarse sand (SB1or (SB2) to obtain a desire sand with a good fineness modulus.

- The studied natural sand can be suitable for the production of concrete.

\section{References}

1. Abrams D.A., (1920). Design of concrete mixtures. Structural Materials Research Laboratory, Lewis Institute, Chicago. 20p.

2. Ahmad S. and Mahmood S., (2008). Effects of Crushed and Natural Sand on the Properties of Fresh and Hardened Concrete, $33^{\text {rd }}$ Conference on Our World in Concrete \& Structures, Singapore 25 - 27 August 2008, Singapore. pp 405-410.

3. Akinboboye, F.A.O., Adegbesan, O.O., Ayegbusi, O.A. \&Oderinde, S.A., (2015). Comparison of the compressive strength of concrete produced using sand from different sources. International Journal of Academic Research in Environment and Geography, 2(1), pp 6-16.

4. Alexander M. and Bertron A., (2013). Performance of cement-based materials in aggressive aqueous environments State-of-the-Art Report, RILEM TC 211-PAE, Vol. 10. 471p.

5. Alexander M.G. and Mindess S., (2005). Aggregates in Concrete, Taylor \& Francis, Abingdon, UK.

6. Alexander, M.G., (1989). Role of Aggregates in Hardened Concrete, Material Science of Concrete III, Skalny, J. and Mindess, S. eds., The American Ceramic Society, Inc. Westerville, Ohio, pp. 119-146.

7. Amey K. B., Neglo K., Tamba S., Johnson A. K. C., Kouto Y.E.and Nayo E., (2014). Caractérisation physique de sables silteux au Togo. AfriqueScience 10(2), pp. $53-69$.

8. ASTM C33/ C33M - 13., (2003). Standard specifications for concrete aggregates, ASTM International, $11 \mathrm{p}$.

9. ASTM C40., (2004). Standard Test Method for Organic Impurities in Fine Aggregates for Concrete. American Society for Testing and Materials, West Conshohocken, PA, USA. 2p.

10. Bashar I. I., Alengaram U.J., Jumaat M.Z., Islam A., (2014). The Effect of Variation of Molarity of Alkali Activator and Fine Aggregate Content on the Compressive Strength of the Fly Ash: Palm Oil Fuel Ash Based Geopolymer. Mortar Advances in Materials Science and Engineering. Volume 2014, Article ID 245473, 13 p. http://dx.doi.org/10.1155/2014/245473

11. Bédérina M., Khenfer M.M., Dheilly R.M., M., (2005). Quéneudec, Reuse of local sand: effect of limestone filler proportion on the rheological and mechanical properties of different sand concretes. Cement and Concrete Research, Vol 35, pp.1172-1179. 
12. Ben Abdelghani F., Maherezi W., Boutouil M., (2014). Caractérisation géotechnique des sédiments de dragage marins en vue de leur valorisation en techniques routières. Déchets Sciences et Techniques $\mathrm{N}^{\circ} 66$. pp. 4-13.

13. Bessong M., Abderrazak E. A., Hell J. V., Claude F., Ndjeng E., Ngos S., Nolla J.D., Dissombo E., Mfoumbeng M. P., Mbang A.R., (2011). Diagenesis in gretaceous formation of Benue in the Northern of Cameroon: Garoua sandstone, World of engineering and applied Sci. ISSN 2249-0582 (3): 58, pp 22490549 .

14. Deer W.A., Howie R A., Zussman J., (1966). An Introduction to the Rock Forming Minerals, Logman. pp. 340-355.

15. Dreux, G., (1978). " Nouveau guide de béton ", 2 eme Edition, Eyrolles, Paris, 60p.

16. Dupain R., Lanchon R., et Saint-Arronan J.C., (2009). "Granulats, sols, ciments et bétons : Caractérisation des matériaux de génie civil par les essais de laboratoire ». $4^{\mathrm{eme}}$ Edition, CASTEILLA, Paris. 240p. Friedman, G.M. \& Sanders, J.E., (1979). Principles of Sedimentology. John Wiley \& Sons, New York. 792p.Folk, R.L. and Ward, W.C. (1957). A Study in the Significance of Grain-Size Parameters. Journal of Sedimentary Petrology, Vol. 27, pp. 3-26. https://doi.org/10.1306/74D706462B2111D78648000102C1865D

17. Glavind, M., Olsen, G.S. and Munch-Petersen, C., (1993). "Packing Calculations and Concrete Mix Design," Nordic Concrete Research, Publication No. 13. pp. 21-34.

18. Goltermann P., Johansen V., Palbful L., (1997). Packing of aggregates: An alternative tool to determine the optimal aggregate mix, ACI Mater. J. 94, pp. 435-443.

19. Hasdemir S., (2004). Metilenmavisideneysonuc, larınınbetonbasınc, dayanımlarınaetkisi. Kongresi Bildiriler Kitab1, Istanbul, Turkey, pp. 615-622.

20. Huang Y. and Wang L., (2017). Effect of Particle Shape of Limestone Manufactured Sand and Natural Sand on Concrete, $6^{\text {th }}$ International Workshop on Performance, Protection \& Strengthening of Structures under Extreme Loading, PROTECT2017, 11-12 December 2017, Guangzhou (Canton), China, Procedia Engineering, Vol. 210, pp. 87-92.

21. Hudson B. P., (1999). "Concrete workability with high fines content sands," Quarry, vol. 7, pp. $22-25$.

22. Institut National de la Statistique, (2010). Troisième recensement Générale de la population et de l'Habitat, Projections démographiques, BUCREP, Vol. III, Tome 3, 91p.

23. Johansen, V. and Andersen, P.J., (1989). Particle Packing and Concrete Properties, Material Science of Concrete II, eds. Skalny, J. and Mindess, S., pp. 111-148.

24. Kamga D.T., Bishweka B. C., Kamdo G., Ngapgue F., (2016). Caractérisation physique des sables de rivières en vue de leur meilleure utilisation dans la confection des bétons. International Journal of Innovation and Scientific Research, ISSN 2351-8014 Vol 25. № 2, pp. 517-527.

25. Kaplan M.F., (1958). The effects of the properties of coarse aggregates on the workability of concrete, Magazine of Concrete Research 29 (10), pp. 63-74.

26. KoiralaM.P. and Joshi E. B. R., (2017). Construction sand, Quality and supply management in infrastructure project" International Journal of Advances in Engineering \& Scientific Research, ISSN: 2349-3607, Vol. 4, pp 01-15.

27. Kronlof A., (1994). Effect of very fine aggregate on concrete strength, Mat. Struct. 27, pp.15-25.

28. Kumar D.P. and Sashidhar C.C., (2018). Effect of fineness modulus of manufactured sand on fresh properties of self-compacting concrete. The Indian Concrete Journal, pp. 77-81.

29. Lefeu. B. et Francy O., (1999). " Module de finesse d'un sable ", Fiche technique de CERIB. 2p.

30. Letouzey R., (1985). Carte phytogéographique du Cameroun au 1/500 000. Institut de Recherche agronomique. Yaoundé-Cameroun et Institut de la Carte Internationale de la Végétation Toulouse-France, Paris, pp. 2-9.

31. Magudeaswaran. P. and Eswaramoorthi. P., (2016). High Performance Concrete Using M Sand. Asian Journal of Research in Social Sciences and Humanities, Vol. 6, pp. 372-386.

32. Mahaut, F., Mok, S., Chateau, X., Roussel, N., Ovarlez, G., (2008). Effect of coarse particle volume fraction on the yield stress and thixotropy of cementitious materials. Cem. Concr. Res., 38, pp. 127-1285.

33. Makhloufi Z., Bederina M., Bouhicha M., Kadri E.H., (2014). "Effect of mineral admixtures on resistance to sulfuric acid solution of mortars with quaternary binders," Physics Procedia, Vol. 55, pp. 329-335.

34. Mane K.M., Kulkarni D.K., Joshi A. A., (2017). Strength and workability of concrete with manufactured sand. International Journal of Engineering Research and Technology, Vol. 10(1), pp. 331-335.

35. Mbowou G.I., Etame J., Ngounouno I., (2011). Géochimie du volcanisme alcalin de la vallée de la haute Bénoué (nord du Cameroun) : aperçu sur le mode de transport du magma dans la lithosphère souscontinentale, Vol. 15, N¹, pp. $14-22$. 
36. Mehta, P.K. and Monteiro, P.J., (1993). Concrete: Structure, Properties, and Materials, $2^{\text {nd }}$ edition, Prentice-Hall, Englewood Cliffs, N.J., p. 36.

37. Mehta, P.K., (1986). Microstructure of Concrete. In Concrete, Structure, Properties and Materials; Hall, W. J., Ed.; Prentice Hall: Washington, DC, USA, pp. 44-50.

38. Mhedhebi M., Gallala W., et Gaied M.E., (2015). Caractérisation et essais de traitement des sables de la formation de Boumar de la région de Sned, VSSS, Harmmamet, pp. 20-22.

39. Munsell Soil Color Chart, (2014). Available at: https://munsell.com/color-products/colorcommunications-products/environmental-color-communication/munsell-soil-color-charts.

40. Ngounouno I., Déruelle B., Demaiffe D., Montigny R., (2003). Petrology of the Cenozoic volcanism in the upper Benue valley, northern Cameroon (Central Africa), Contributions to Mineralogy and Petrology 145, pp. 87-106.

41. Ngounouno I., Moreau C., Déruelle B., Demaiffe D., Montigny R., (2001). Pétrologie du complexe alcalin sous-saturé de Kokoumi (Cameroun), Bulletin de la Société Géologique de France 172, pp. 675686.

42. Ngugi, H.N., Mutuku, R.N. and Gariy, Z.A., (2014). Effects of Sand Quality on Compressive Strength of Concrete: A Case of Nairobi County and Its Environs, Kenya. Open Journal of Civil Engineering, Vol. 4, pp. 255-273. http://dx.doi.org/10.4236/ojce.2014.43022

43. Normes NF EN 933-1., (1997). « Essais pour déterminer les caractéristiques géométriques des granulats, Partie 1 : Détermination de la granularité Analyse granulométrique par tamisage », AFNOR.

44. Normes NF EN 933-8., (1999). « Essais pour déterminer les caractéristiques géométriques des granulats, Partie 8 : Evaluation des fines équivalent de sable », AFNOR.

45. Obla K., (2011). Variation in concrete performance due to aggregates - Part VII of concrete quality series, Concrete Infocus, 10, pp. 9-14.

46. Olivry., (1986). Fleuves et rivières du Cameroun-MERRESS-ORSTOM, ISBN2- 7099-0804-2, 733p.

47. Pedersen B., (2011). Manufactured sand in concrete - Effect of particle shape on workability. COIN Project Report 34p.

48. Poloju K.K., Anil V., Manchiryal R.K., (2017). Properties of Concrete as Influenced by Shape and Texture of Fine Aggregate. American Journal of Applied Scientific Research. Vol. 3, No. 3, pp 28-36.

49. Quiroga P.N. And Fowler D.W., (2003). The effects of aggregates characteristics on the performance of Portland Cement concrete, Research Report ICAR - 104-1F, Project Number 104, 382p.

50. Raunet M., (2003). Quelques clés morphologiques pour le Nord Cameroun à l'usage des agronomes. Rapport projet ESA/SC, Cameroun, 24 p.

51. Reddy M.Y., Swetha D.V. and Dhani S.K., (2015). "Study on properties of concrete with manufactured sand as replacement to natural sand," International Journal of Civil Engineering and Technology, Vol. 6, No. 8, Article ID IJCIET_06_08_004,pp. 29-42.

52. Saaid M.I., Kamat D., Muhammad S., (2011). Characterization of Malaysia Sand for Possible Use as Proppant American International Journal of Contemporary Research. Vol. 1 No.1, pp 37-44.

53. Sabih G., Tarefder R.A., Jamil S.M., (2016). Optimization of gradation and fineness modulus of naturally fine sands for improved performance as fine aggregate in concrete. Procedia Engineering 145, pp 66-73.

54. Saidi H., Brahim M. et Gueddari M., (2004). Caractérisation granulométrique et minéralogique des sédiments de surface de la frange littorale sidi Bou Said-la goulette. Bull. Inst. Natn. Scien. Tech. Mer de Salammbô, Vol. 3, pp. 97-106.

55. Shilstone J.M., (1999) "The aggregate: the most important value-adding component in concrete," in Proceedings of the 7th Annual Symposium, International Center for Aggregates Research. (ICAR), Austin, Tex, USA.

56. Sujatha T, Kannapiran K, Nagan S., (2012). Strength assessment of heat cured geopolymer concrete slender column, Asian Journal of Civil Engineering, Vol. 13, pp. 635-646.

57. Tamfuh, P.A., Woumfo, E.D., Bitom, D., Njopwouo, D., (2011). Petrological, physico-chemical and mechanical characterization of the topomorphicvertisols from the Sudano-sahelian region of North Cameroon. The Open Geology Journal 5: pp.33-55.

58. Tchouani Nana J.M. et Callaud M., (2004). " Cours de mécanique des sols : Tome I - Propriétés des sols" $108 \mathrm{p}$, www.almohandiss.com

59. Tebbal N. and Rahmouni Z.E., (2016). Influence of Local Sand on the Physicomechanical Comportment and Durability of High Performance Concrete, Advances in Civil Engineering Volume 2016, 10 p.

60. Terzaghi K., Peck R.B., Mesri G., (1996). Soil mechanics in engineering practice, third edition, 592p.

61. United Nations, WPP, (2011). World Population Prospects, 2010 revision, New York, Vol. I, 503p. 
62. Westerholm M., Lagerblad B., Silfwerbrand J., Forssberg E., (2012). Influence of fine aggregate characteristics on the rheological properties of mortars. Cem. Concr. Compos, 30, pp. 274-282.

63. Wilde, P., Holden, J., Isselhardt, C., (1970). Non-destructive wet weighing of marine sediments: Marine Geology, Vol. 8, p. 173-178.

64. Xudong C., Huang W. and Zibou J., (2012). Effect of moisture content on compressive and split tensile strength of concrete Indian Journal of Engineering and Laterial Sciences, Vol. 19, pp. 427-435. 